\title{
THE EFFECTIVENESS OF CLUSTERING AND FREEWRITING AS PREWRITING ACTIVITY FOR STUDENT'S WRITING ABILITY IN IKIP BUDI UTOMO MALANG
}

\author{
Ike Dian Puspitasari \\ Program Studi Pendidikan Bahasa Inggris \\ IKIP Budi Utomo Malang \\ Jalan Citandui 46 Malang \\ ikedianpuspitasari@budiutomomalang.ac.id
}

\begin{abstract}
Writing is productive skill which demands students to think logically. In this research, the researcher used two groups consisting Group A (20 students) who was given clustering as prewriting activity, and Group B (20 students) who was given freewriting as their prewriting activity. The result shows that clustering which was used by Group A did not show significant effect toward students' writing ability. While, freewriting which is used in Group B shows significant effect towards students' writing ability. The two different results found might be caused by grammatical and vocabulary items scores in students writing draft.
\end{abstract}

Writing force students' logical thinking to delivering their idea as written product. It does not only demand English fluency, but also English accuracy. In transforming knowledge, writing instruction increase role in foreign language education as writing effectively (Weigle, 2002).

Richards and Renanadya (2002) assumes that writing is one of highest skill for EFL because it demands to generate and organize idea, and also transfer it become a good paragraph or essay. Hence, the way to transfer the ideas also consider the vocabulary items used, mechanics, and grammatical.

In order to arrange the ideas into a good paragraph or essay, students do prewriting activity. "The term "pre-writing" has two different meanings. It can mean the stage before children learn writing, which is referred to as hand skills. The other meaning, which is the concern of this article, points to the first stage of the writing process, followed by drafting, revision, editing and publishing" (Mogahed, 2013).Zheng and Dai (2012) adds that "the prewriting activities generate ideas which can encourage a free flow of thoughts and help students discover both what they want to say and how to say it on paper".

Brown (2007) mentions some prewriting activities, such as clustering, freewriting, brainstorming, reading, and so on. Mogahed (2013) states that prewriting activity is the basic stage done in writing before continue to next stages such as drafting and revising, while it also encourages students to write.

Mahnam and Nejadansari (2012) applied concept mapping in their research. They used 2 groups consist 11 and 12 participants. The experimental group was given mind mapping which is similar to clustering, reading relevant texts, and negotiation. The result shows that the prewriting is significant.

In this research, the researcher tries to apply clustering and freewriting as prewriting activity to be used as prewriting activity. Pretest and post test will be given for those two groups.Based on the background above, the statements of problem are as follows:

1. How is the effect of clustering applied as prewriting activity for students' writing ability in IKIP Budi Utomo Malang?

2. How is the effect of freewriting applied as prewriting activity for students' writing ability in IKIP Budi Utomo Malang?

\section{METHOD}

This research used quasi experimental as research design. The researcher used three groups consisting 20 students for each group. Group A as Experimental Group 1 that was given clustering, and Group B as Experimental Group 2 that was given freewriting. Each groups was given same topic for pretest and posttest. Each group also got same material or explanation. The research was done in 5 meetings for each group. Pretest was given in Meeting 1. Students wrote 
their idea regarding to certain topics in 100 minutes. In meeting 2, teacher explained material (descriptive text) and asked them to prepare their ideas in the form of clustering or freewriting (experimental groups). Then, they develop their ideas into a good descriptive text based on their draft in Meeting 3. In meeting 4, they revise their first writing draft by considering teacher's feedback. Hence, they wrote their final writing product in Meeting 5.

\section{FINDING}

Posttest was given for Group A, Group B in Meeting 5. The first step, researcher analyze the normality of three groups. Here the result of normality test done by researcher:

Table 3.1 Normality Test

\begin{tabular}{|l|l|r|}
\hline \multicolumn{2}{|l|}{} & \multicolumn{1}{|c|}{$\begin{array}{c}\text { Unstandardize } \\
\mathrm{d} \text { Residual }\end{array}$} \\
\hline $\mathrm{N}$ & \multicolumn{2}{|l|}{20} \\
\hline Normal Parameters & $\mathrm{a}$ \\
& Mean & .0000000 \\
\cline { 2 - 3 } & Std. Deviation & 4.32426678 \\
\hline $\begin{array}{l}\text { Most Extreme } \\
\text { Differences }\end{array}$ & Absolute & .112 \\
\cline { 2 - 3 } & Positive & .112 \\
\cline { 2 - 3 } & Negative & .085 \\
\hline Kolmogorov-Smirnov Z & & .962 \\
\hline Asymp. Sig. (2-tailed) & \\
\hline \multicolumn{2}{|l|}{ a. Test distribution is Normal. } & \\
\hline
\end{tabular}

From the Table 3.1, the significant value is 0.962 which is bigger than á $=0.05$. Hence, it can be concluded that the data is normal. Hence, the homogeneity was also analyzed by using SPSS. Here the result of homogeneity test.

Table 3.2 Test of Homogeneity of Variances

\begin{tabular}{|l|r|r|r|r|}
\hline & $\begin{array}{c}\text { Levene } \\
\text { Statistic }\end{array}$ & df1 & \multicolumn{1}{c|}{ df2 } & \multicolumn{1}{c|}{ Sig. } \\
\hline Group A & 10.252 & 4 & 15 & .000 \\
\hline Group B & 1.383 & 4 & 15 & .287 \\
\hline
\end{tabular}

While the significant value $(0.287)$ is also bigger than á $=0.05$, it can be concluded that the data is homogeny. After finding the normality value and homogeneity value, the researcher continue to analyze whether clustering and freewriting significant or not. Here the result of data analysis:

Table 3.3 ANOVA

\begin{tabular}{|l|l|r|r|r|r|r|}
\hline & & $\begin{array}{c}\text { Sum of } \\
\text { Squares }\end{array}$ & df & Mean Square & F & \multicolumn{1}{c|}{ Sig. } \\
\hline \multirow{3}{*}{ Group A } & Between Groups & 49.286 & 4 & 12.321 & .520 & .723 \\
\cline { 2 - 7 } & Within Groups & 355.714 & 15 & 23.714 & & \\
\cline { 2 - 7 } & Total & 405.000 & 19 & & & \\
\hline \multirow{3}{*}{ Group B } & Between Groups & 517.560 & 4 & 129.390 & 4.076 & .020 \\
\cline { 2 - 7 } & Within Groups & 476.190 & 15 & 31.746 & & \\
\cline { 2 - 7 } & Total & 993.750 & 19 & & & \\
\hline
\end{tabular}


Group A was given clustering as students' prewriting activity. Group A showed that significant value 0.723 in df 19 (N-1) which is bigger than á $=0.05$. Hence, $\mathrm{Ha}_{1}$ is rejected. There is no significant effect between clustering as prewriting activity and students' writing ability. For another group, Group B was given Freewriting as students' prewriting activity. from Group B, it can be seen that the significant value is 0.020 . It is bigger than á=0.05. Thus, $\mathrm{Ha}_{2}$ is accepted. For Group B, it can be concluded that there is significant effect between freewriting and students' writing ability.

\section{DISCUSSION}

The result showed that clustering was not significant towards students' writing ability. However, the second prewriting activity (freewriting) showed significant effect towards students' writing ability. The first result differs to Mogahed (2013) who found that mind mapping that is similar to clustering showed significant effect towards students' writing ability. From the teacher's feedback, the low scores from four aspect (content, grammatical error, vocabulary items, and mechanics) were in grammatical error and vocabulary items. Compared with Group B that was given freewriting, grammatical error and vocabulary items have better score than Group A. It might be influenced by the first draft (clustering and freewriting). In clustering, students only write down their ideas in some keywords. However, the freewriting contains more vocabulary items and also consider grammatical error. Hence, it influence their next draft and their score of final writing.

\section{CONCLUSION AND SUGGESTION}

The data analysis of Group A shows that there is no significant effect between clustering as prewriting activity and students' writing ability. However, the second result of Group B shows that there is significant effect between freewriting as prewriting ability and students' writing ability. Both groups are normal and homogeny. It means that there is not any different ability from one student to other students' within group and between group.

For next research, it may be better if the variable is controlled. For instance, the control of gender, age, and their English proficiency. Therefore, it can be found whether the prewriting ability applied is significant or not by considering those controlled variables.

\section{ACKNOWLEDGEMENT}

This research was done by Ike Dian Puspitasari, MPd in 2017. The writing class in IKIP Budi Utomo Malang was used in conducting the research. All gratitude was given for all people who participate to help conducting this research.

\section{REFERENCE}

Brown, H.D.2007.Principles of Language Teaching and Learning. New York: Pearson Education Inc.

Mahnam, L., \&Nejadansari, D. 2012. The Effect of Different Pre-Writing Strategies on Iranian EFL Writing Achievement. International Education Strategies Vol. 5 No. 1 (www.csenet.org/ies)

Mogahed, M. M. 2013. Planning Out PreWriting Activities. International Journal of English and Literature Vol 4 (3) pp. 60-88 (www.academicjournals.org/IJEL) 
12\| Ike Dian, The Effectiveness Of Clustering ..... 